\section{UCDNN}

LIBRARY
University of Connecticut OpenCommons@UConn

September 2004

\title{
Kentucky Bluegrass Response to Potassium and Nitrogen Fertilization
}

\author{
R.J.M. Fitzpatrick
}

Karl Guillard

University of Connecticut Department of Plant Science, karl.guillard@uconn.edu

Follow this and additional works at: https://opencommons.uconn.edu/plsc_articles

\section{Recommended Citation}

Fitzpatrick, R. J.M. and Guillard, Karl, "Kentucky Bluegrass Response to Potassium and Nitrogen Fertilization" (2004). Plant Science Articles. 3.

https://opencommons.uconn.edu/plsc_articles/3 


\title{
Kentucky Bluegrass Response to Potassium and Nitrogen Fertilization
}

\author{
Richard J. M. Fitzpatrick and Karl Guillard*
}

\begin{abstract}
The response of Kentucky bluegrass (Poa pratensis L.) to potassium (K) fertilization has been inconsistent. The objective of this research was to determine the effects of $K$ fertilization across varying nitrogen $(\mathrm{N})$ rates and clipping management on Kentucky bluegrass clipping yields, quality, tissue $\mathrm{K}$ concentrations, apparent $\mathrm{N}$ recovery, and $N$ use efficiency. A $2 \times 4 \times 4$ factorial was arranged in a splitplot design and repeated across two years. Main plots were clipping treatments (returned vs. removed) and subplots were $\mathrm{N}$ rates $(0,98$, 196 , and $\left.294 \mathrm{~kg} \mathrm{ha}^{-1} \mathrm{yr}^{-1}\right)$ in combination with $\mathrm{K}$ rates $(0,81,162$, and $243 \mathrm{~kg} \mathrm{ha}^{-1} \mathrm{yr}^{-1}$ ). There was no positive effect of $\mathrm{K}$ on clipping yields and quality even though soil extractable $\mathrm{K}$ levels tested low. Higher $\mathrm{K}$ rates, however, increased $\mathrm{N}$ recovery and use efficiency for all but the highest $N$ rate. Tissue $K$ response to $K$ fertilization was nonlinear. Yield and quality responses were not correlated to tissue $K$ concentration. Nonexchangeable $K$ levels were high in the native soil, and may have provided an additional source of $K$ for bluegrass. The results suggest that extractable $K$ values alone may not adequately predict available $K$ to Kentucky bluegrass in this sandy loam soil.
\end{abstract}

$P$ REvious STUDIES REPORT differing $\mathrm{K}$ effects on grass growth and quality. Turner and Hummel (1992) found few beneficial growth effects from $\mathrm{K}$ applications to cool-season turfgrasses, even when extractable soil K concentrations were relatively low. Sartain (1993) noted in studies of hybrid turf bermudagrass [Cynodon dactylon (L.) Pers. $\times$ C. transvaalenis Burtt Davy] that applications of $\mathrm{K}$ improved clipping yields when clippings were removed, while similar $\mathrm{K}$ applications on perennial ryegrass (Lolium perenne $\mathrm{L}$.) did not influence clipping yields. Three years of $\mathrm{K}$ fertilization for common bermudagrass [Cynodon dactylon (L.) Pers.] were needed before a forage yield response was observed by Nelson et al. (1983). Inadequate exchangeable K in the soil resulted in reduced forage yield from selected coolseason grasses (Wedin, 1974). In contrast, K applications alone had no effect on turf Kentucky bluegrass grown in soils with low soil test $\mathrm{K}$ values, independent of the K rate applied (Ebdon et al., 1999).

The need for $\mathrm{K}$ by turfgrasses may be affected by $\mathrm{N}$ availability. Schmidt and Breuninger (1981) reported that fertilization of Kentucky bluegrass with $300 \mathrm{~kg} \mathrm{~N}$ $\mathrm{ha}^{-1} \mathrm{yr}^{-1}$ significantly decreased leaf $\mathrm{K}$ concentrations when compared with half that $\mathrm{N}$ rate. Increasing the amount of $\mathrm{N}$ applied to Kentucky bluegrass without a corresponding increase in $\mathrm{K}$ application reduced concentrations of leaf K (Carroll and Petrovic, 1991). When $\mathrm{N}$ and $\mathrm{K}$ were applied in a nutrient solution experiment, increasing $\mathrm{K}$ above $100 \mathrm{mg} \mathrm{kg}^{-1}$ generally had an ad-

Dep. of Plant Science Unit 4067, Univ. of Connecticut, 1376 Storrs Road, Storrs, CT 06269-4067. Received 30 April 2003. *Corresponding author (karl.guillard@uconn.edu).

Published in Crop Sci. 44:1721-1728 (2004).

(c) Crop Science Society of America

677 S. Segoe Rd., Madison, WI 53711 USA verse effect on most growth measurements of Kentucky bluegrass with $65 \mathrm{mg} \mathrm{N} \mathrm{kg}^{-1}$ (Monroe et al., 1969). With $130 \mathrm{mg} \mathrm{N} \mathrm{kg}{ }^{-1}$, however, best grass development was observed at the $200 \mathrm{mg} \mathrm{K} \mathrm{kg}^{-1}$ rate. This suggested the need for increased $\mathrm{K}$ when the amount of $\mathrm{N}$ is increased. Studies of Kentucky bluegrass by Carroll and Petrovic (1991) showed that small changes in the $\mathrm{N}: \mathrm{K}$ fertilizer ratio, such as 2:1 to 1:1, did not appreciably change leaf osmotic potential, but larger ratio changes of $10: 1$ to 1:5 significantly decreased (made more negative) leaf osmotic potential. Christians et al. (1981) and Ebdon et al. (1999) observed an interaction between $\mathrm{N}$ and $\mathrm{K}$ on Kentucky bluegrass where shoot growth increased in response to $\mathrm{K}$ at low levels of $\mathrm{N}$ but decreased at high $\mathrm{N}$ levels. Snyder and Cisar (2000) reported that increasing $K$ rates on bermudagrass beyond a $N / K$ fertilizer ratio of 1.0 to 2.0 had no effect on its appearance, growth or root weight. High $\mathrm{N}$ fertilizer rates with high $\mathrm{K}$ fertilizer rates were shown by Pellet and Roberts (1963) to give better heat resistance to Kentucky bluegrass than high $\mathrm{N}$ rates with low $\mathrm{K}$ rates.

Plants will typically absorb more $\mathrm{K}$ than is required for optimum growth. The excessive absorption is termed "luxury consumption." However, recent studies indicate that frequently mowed turfgrasses may not exhibit luxury consumption of K. Miller (1999) reported no increases in tissue $\mathrm{K}$ concentrations at applications $>74$ $\mathrm{kg} \mathrm{K} \mathrm{ha}{ }^{-1} \mathrm{mo}^{-1}$ in studies with hybrid bermudagrass grown on loamy sand soils and sand-peat rootzone mixes. Also, Sartain (2002) noted that the application of additional $\mathrm{K}$ above a rate of $9.8 \mathrm{~g} \mathrm{~m}^{-2} 90 \mathrm{~d}^{-1}$ to hybrid bermudagrass did not result in an increase in tissue $\mathrm{K}$. Similar results were obtained by Snyder and Cisar (2000), indicating that increasing K fertilization on hybrid bermudagrass relative to $\mathrm{N}$ fertilization did not provide proportionate increases in tissue K. Luxury consumption of $\mathrm{K}$ was not observed with Kentucky bluegrass turf with increased $\mathrm{K}$ fertilization (Schmidt and Breuninger, 1981).

Most of the total $\mathrm{K}$ in soils is associated with primary minerals and nonexchangeable forms. Nonexchangeable soil $\mathrm{K}$ is thought to be slowly released into the soil solution and to contribute only a minor amount of plant available K during the growing season. Studies by Güzel et al. (2001), however, indicate a strong positive correlation between the amounts of nonexchangeable and the exchangeable K. Relatively high amounts of exchangeable and nonexchangeable $\mathrm{K}$ in the soil may account for a lack of response by plants when fertilizer $\mathrm{K}$ is applied (López-Piñeiro and García Navarro, 1997). Sparks (1980) reported no positive yield responses of corn (Zea mays L.) to fertilizer $\mathrm{K}$ because of either subsoil $\mathrm{K}$ or large reserves of feldspar and mica, which release sufficient $\mathrm{K}$ to meet crop needs. A study of creeping bentgrass (Agrostis palustris Huds.) suggested that K release from 
primary minerals in several pure sand rootzone mixes was proceeding at rates sufficient to satisfy bentgrass $\mathrm{K}$ requirements (Dest and Guillard, 2001).

Because $\mathrm{K}$ fertilization to turfgrass has produced inconsistent results in previously reported experiments, further study was warranted to determine if $\mathrm{K}$ application to Kentucky bluegrass would elicit growth or quality responses. Therefore, the objective of this study was to determine the effects of differing $\mathrm{K}$ fertilization rates across varying $\mathrm{N}$ rates and clipping management on Kentucky bluegrass clipping yield, turf quality, tissue $\mathrm{K}$ concentration, and $\mathrm{N}$ recovery and use efficiency.

\section{MATERIALS AND METHODS}

A field experiment was conducted at the University of Connecticut's Plant Science Research and Teaching Farm, Storrs, CT, in 2000 and 2001. The soil was a Paxton fine sandy loam (coarse-loamy, mixed, active, mesic Oxyaquic Dystrudept) with a pre-treatment $\mathrm{pH}$ of 5.1 (1:1, soil:water), and modifiedMorgan (ammonium acetate, $\mathrm{pH}$ 4.8; McIntosh, 1969) extractable $\mathrm{Ca}, \mathrm{Mg}, \mathrm{P}$, and $\mathrm{K}$ concentrations of $643,89,4$, and $75 \mathrm{mg}$ $\mathrm{kg}^{-1}$, respectively. These soil values are considered Medium, Medium-High, Medium, and Low, respectively, according to our current soil test ratings.

The experiment was arranged as a $2 \times 4 \times 4$ factorial in a split-plot design with three replicates. Main plots were two clipping treatments (returned vs. removed) and subplots were four rates of $\mathrm{K}\left(0,81,162\right.$, and $\left.243 \mathrm{~kg} \mathrm{ha}^{-1} \mathrm{yr}^{-1}\right)$ in combination with four rates of $\mathrm{N}\left(0,98,196\right.$, and $\left.294 \mathrm{~kg} \mathrm{ha}^{-1} \mathrm{yr}^{-1}\right)$ applied in split applications. During each growing season, the split fertilizer applications $\left(49 \mathrm{~kg} \mathrm{~N}^{-1}\right.$ and $40.5 \mathrm{~kg} \mathrm{~K}^{-1}$ increments) were applied by hand spreading in May and September for the $98 \mathrm{~kg} \mathrm{~N} \mathrm{ha}^{-1}$ and $81 \mathrm{~kg} \mathrm{~K} \mathrm{ha}^{-1}$ rates; May, June, September, and October for the $196 \mathrm{~kg} \mathrm{~N} \mathrm{ha}^{-1}$ and $162 \mathrm{~kg}$ $\mathrm{K} \mathrm{ha}^{-1}$ rates; and May, June, July, August, September, and October for the $294 \mathrm{~kg} \mathrm{~N} \mathrm{ha}^{-1}$ and $243 \mathrm{~kg} \mathrm{~K}^{-1}$ rates. The $\mathrm{N}$ source was a 60:40 mixture of soluble:slow release $\mathrm{N}$ containing $\mathrm{NH}_{4} \mathrm{NO}_{3}$ (34-0-0, N-P-K) and poly-coated sulfur urea (29-0-0). The $\mathrm{K}$ source was $\mathrm{K}_{2} \mathrm{SO}_{4}(0-0-42)$. Individual plot size was $1.5 \times 1.5 \mathrm{~m}$. Calcitic limestone was applied on 9 June 2000 and 14 May 2001 at 2,450 $\mathrm{kg} \mathrm{CaCO}_{3} \mathrm{ha}^{-1}$, and on 27 Aug. 2001 at $3,430 \mathrm{~kg} \mathrm{CaCO}_{3} \mathrm{ha}^{-1}$, as per soil test recommendations. All plots received $\mathrm{P}$ as $0-20-0$ at $49 \mathrm{~kg} \mathrm{ha}^{-1}$ before the application of $\mathrm{N}$ and $\mathrm{K}$ treatments. No supplemental irrigation was applied during either growing season. Herbicides for grassy and broadleaf weeds and insecticides for scarab beetle grubs were applied as needed.

Plots were established in May 1999 with a Kentucky bluegrass and fine leaf fescue sod containing 30\% 'Midnight' Kentucky bluegrass, 20\% 'Adelphi' Kentucky bluegrass, 20\% 'America' Kentucky bluegrass, 20\% 'Touchdown' Kentucky bluegrass, 5\% 'Cindy' creeping red fescue (Festuca rubra ssp. rubra), and 5\% 'Southport' chewings fescue (Festuca rubra ssp. commutata). Plots were irrigated on a regular basis for 2 wk until the sod was rooted. During the growing season of 1999, experimental treatments were applied and all plots were irrigated as needed, but data from the establishment year is not reported. Irrigation was withheld beginning on 1 August 1999.

Plots were maintained at a mowing height of $4 \mathrm{~cm}$. Before each mowing, a $22-\mathrm{cm}^{2}$ quadrat, set at a $4-\mathrm{cm}$ height, was placed randomly within each plot. Hand shears were used to harvest all tissue above $4 \mathrm{~cm}$ within the quadrat area. After sampling, plots were mowed using a $53-\mathrm{cm}$ wide mulching mower (John Deere model JS60, Deere \& Company, Moline, IL, USA), with clippings either returned or removed with a bagger attachment. Samples were dried in a forced-draft oven $\left(70^{\circ} \mathrm{C}\right)$ until a constant weight was reached, weighed, and then ground in a Udy Mill to pass through a $0.5-\mathrm{mm}$ screen. Weekly clipping samples were combined into five sampling periods for each year. Sampling periods corresponded approximately to the months of the growing season (Sampling Period $1=$ May-June, Sampling Period 2 = June-July, Sampling Period $3=$ July-August, Sampling Period $4=$ August-September, Sampling Period 5 = September-October).

Tissue samples were analyzed for total $\mathrm{N}$ concentrations using a LECO FP-2000 Carbon/Nitrogen Analyzer (LECO Corp., St. Joseph, MI). Apparent $\mathrm{N}$ recovery was calculated using the difference method as $\left[\left(\mathrm{N}\right.\right.$ uptake at $N_{x}-\mathrm{N}$ uptake at $\left.N_{\mathrm{o}}\right) /\left(\right.$ applied $\mathrm{N}$ at $\left.\left.N_{x}\right) \times 100 \%\right]$, where $x=\mathrm{N}$ rate $>0$; where the uptake of $\mathrm{N}$ was calculated as clipping dry weight $X$ $\mathrm{N}$ concentration. Nitrogen use efficiency was calculated as: [(yield at $N_{x}$ - yield at $N_{\mathrm{o}}$ )/applied $\mathrm{N}$ at $N_{x}$ ], where $x=\mathrm{N}$ rate $>0$, in units of $\mathrm{g}$ dry matter produced per $\mathrm{g} \mathrm{N}$ applied (Zemenchik and K.A. Albrecht, 2002). Because $N_{\mathrm{o}}$ treatments occurred in varying clipping management and $\mathrm{K}$ rate treatments, the values for $N_{\mathrm{o}}$ in the above equations were obtained from the same block, clipping treatment, and $\mathrm{K}$ rate treatment as the respective $N_{x}>0$ plot for which $\mathrm{N}$ recovery and use efficiency was being calculated.

Potassium was extracted from tissue samples with neutral ammonium acetate to estimate plant total $\mathrm{K}$ concentrations (Chapman and Pratt, 1978). This method was chosen because of its speed of analysis and safer use compared with acid digestion or combustion procedures. In plants, $\mathrm{K}$ is not bound in forms requiring sample digestion for total $\mathrm{K}$ estimation. Extraction of tissue $\mathrm{K}$ with weak acids such as ammonium acetate or dilute $\mathrm{HCl}$ can reliably estimate $\mathrm{K}$ compared with total $\mathrm{K}$ determination by wet acid digestions or combustion methods (Baker and Greweling, 1967; Sahrawat, 1980; Hunt, 1982; Percell et al., 1995). Sample extracts were analyzed with a Technicon AutoAnalyzer Flame Photometer IV for the determination of $\mathrm{K}$ concentration.

Soil samples were taken from each plot on 9 Nov. 2000 and 18 Oct. 2001 and on 4 May 2001 and 20 May 2002, and analyzed for modified-Morgan extractable K. Four cores were taken per plot to a depth of 10 to $15 \mathrm{~cm}$ with a $1.9-\mathrm{cm}$ diameter soil probe, mixed, and then subsampled. Soil samples were also taken from the untreated alleyways (which were representative of the control plots) to the same depth with the same probe and analyzed for nonexchangeable $\mathrm{K}$ employing the boiling $1 M$ nitric acid method (Helmke and Sparks, 1996). Soil extracts were analyzed by flame photometery for determination of nonexchangeable K concentration. Soil samples from the untreated alleyways were also analyzed for the presence of primary and clay minerals using X-ray diffraction analysis (Mitchell, 1993).

Visual quality estimates for turf were at each Sampling Period using a rating system from 1 to 9 where $1=$ lowest quality, $6=$ minimally acceptable, and $9=$ highest quality. Ratings were a function of color and density (Skogley and Sawyer, 1992).

Treatment effects on clipping dry matter yield, apparent $\mathrm{N}$ recovery, and $\mathrm{N}$ use efficiency were analyzed by ANOVA with repeated measures. Because treatments were applied to the same respective plots in 2000 and 2001, years were treated as the repeated measure. Effects of $\mathrm{N}$ and $\mathrm{K}$ were further evaluated using single-degree-of-freedom orthogonal polynomial contrasts to determine linear (L), quadratic (Q), and cubic (C) and interaction responses (i.e., $\mathrm{KL} \times \mathrm{NL}, \mathrm{KL} \times$ $\mathrm{NQ}$, etc.). Based on these contrast analyses, surface response models were generated using equations based on the significant $(P<0.05)$ orthogonal polynomial terms as indicated 
by the ANOVA (Schabenberger and Pierce, 2002). Tissue K concentrations and quality ratings were analyzed using ANOVA with repeated measures; the 10 Sampling Periods (five in each year) served as the repeated measure. Single-degree-of-freedom orthogonal polynomial contrasts where applied also to these analyses as described above, and a separate series of single-degree-of-freedom orthogonal polynomial contrasts were conducted to determine the trend response of tissue K concentrations in response to $\mathrm{K}$ rates for each individual Sampling Period. Because the experiment was a replicated design, treatment means were used to generate the regression equations used to describe the surface and trend responses (Gomez and Gomez, 1984). The SAS procedures MIXED and REG were used for data analyses (SAS, 1999).

\section{RESULTS}

\section{Extractable Soil Potassium Concentrations}

Fall and spring extractable soil $\mathrm{K}$ concentrations were affected by both $\mathrm{K}$ and $\mathrm{N}$ rates (Table 1). Extractable soil $\mathrm{K}$ in fall-collected samples increased linearly with increasing $\mathrm{K}$ rates but decreased linearly with increasing $\mathrm{N}$ rates (Fig. 1A). Spring extractable K responded similarly, except at the highest $\mathrm{N}$ and $\mathrm{K}$ rate combinations, where the response was curvilinear because of the significant $\mathrm{KC} \times \mathrm{NQ}$ interaction (Fig. 1B). It was expected that extractable soil $\mathrm{K}$ concentrations would increase as $\mathrm{K}$ rates increased. The negative response of extractable soil K concentrations to $\mathrm{N}$ rate, however, was probably a result of $\mathrm{K}$ removal by plant uptake that increased with increasing $\mathrm{N}$ rates (data not shown).

\section{Clipping Dry Matter Yield and Quality}

Applied fertilizer $\mathrm{K}$ had no effect on clipping dry matter yields (Table 1). Positive yield responses were a function of increasing $\mathrm{N}$ rates and returning clippings. The lack of a response to $\mathrm{K}$ fertilization was surprising considering that the initial soil extractable K concentration was $75 \mathrm{mg} \mathrm{kg}^{-1}$, which is classified as low under our present soil-test ratings. Even at the high $\mathrm{N}-0 \mathrm{~K}$ treatment combination, which decreased extractable soil K concentrations (Fig. 1), yields were comparable to yields obtained at the higher $\mathrm{K}$ rate combinations with $\mathrm{N}$.

No positive effect was observed for K on turf quality, and positive effects were a function only of increasing $\mathrm{N}$ rates and returning clippings (Table 2). Increasing $\mathrm{K}$ rates significantly decreased quality at the highest $\mathrm{N}$ rate (Fig. 2), but the decrease in absolute rating values ( $\approx 6.5$ to just below 6.4 ) probably has little, if any, practical consequences.

\section{Tissue Potassium Concentration}

Tissue $\mathrm{K}$ concentration response to $\mathrm{K}$ rate varied with the time of season when samples were collected (significant $\mathrm{K}$ rate $\times$ Sampling Period interaction, Table 2). Contrast analysis of the $\mathrm{K}$ rate $\times$ Sampling Period interaction revealed that tissue $\mathrm{K}$ concentrations responded in a curvilinear manner (either quadratic or cubic) across $\mathrm{K}$ rates in all Harvest Periods, except at the last sampling in 2001, when there was no response to $\mathrm{K}$
Table 1. Analyses of variance summary indicating significant source effects on fall and spring extractable soil $\mathbf{K}$ concentrations, Kentucky bluegrass clipping dry matter yield (DMY), apparent $\mathrm{N}$ recovery (ANR), and $\mathrm{N}$ use efficiency (NUE).

\begin{tabular}{|c|c|c|c|c|c|c|c|}
\hline Source & df & Fall $\mathbf{K}$ & Spring $\mathbf{K}$ & DMY & df & ANR & NUE \\
\hline Clipping (Cp) & 1 & NS & NS & $* *$ & 1 & NS & NS \\
\hline $\mathbf{N}$ rate $(\mathrm{N})$ & 3 & & & & 2 & & \\
\hline Linear (L) & 1 & $* *$ & $* *$ & $* *$ & 1 & NS & \\
\hline Quad. (Q) & 1 & NS & NS & $*$ & 1 & NS & NS \\
\hline Cubic (C) & 1 & NS & NS & NS & & & \\
\hline$K$ rate $(\mathbf{K})$ & 3 & & & & 3 & & \\
\hline L & 1 & $* *$ & $* *$ & NS & 1 & $* *$ & $* *$ \\
\hline $\mathbf{Q}$ & 1 & NS & NS & NS & 1 & NS & NS \\
\hline C & 1 & NS & NS & NS & $\mathbf{1}$ & NS & NS \\
\hline $\mathbf{K} \times \mathbf{N}$ & 9 & & & & 6 & & \\
\hline $\mathbf{K L} \times \mathbf{N L}$ & 1 & NS & $* *$ & NS & 1 & $*$ & $* *$ \\
\hline $\mathbf{K L} \times \mathbf{N Q}$ & 1 & NS & NS & NS & 1 & NS & NS \\
\hline $\mathbf{K L} \times \mathbf{N C}$ & 1 & NS & NS & NS & & & \\
\hline $\mathbf{K Q} \times \mathbf{N L}$ & 1 & NS & NS & NS & 1 & NS & NS \\
\hline $\mathbf{K Q} \times \mathbf{N Q}$ & 1 & NS & NS & NS & 1 & NS & NS \\
\hline $\mathbf{K Q} \times \mathbf{N C}$ & 1 & NS & NS & NS & & & \\
\hline $\mathbf{K C} \times \mathbf{N L}$ & 1 & NS & $*$ & NS & 1 & NS & NS \\
\hline $\mathbf{K C} \times \mathbf{N Q}$ & 1 & NS & $*$ & NS & 1 & NS & NS \\
\hline $\mathbf{K C} \times \mathbf{N C}$ & 1 & NS & NS & NS & & & \\
\hline $\mathbf{C p} \times \mathbf{N}$ & 3 & NS & NS & NS & 2 & NS & NS \\
\hline $\mathbf{C p} \times \mathbf{K}$ & 3 & NS & NS & NS & 3 & NS & NS \\
\hline $\mathbf{C p} \times \mathbf{K} \times \mathbf{N}$ & 9 & NS & NS & NS & 6 & NS & NS \\
\hline Year (Y) & 1 & $* *$ & $* *$ & $* *$ & 1 & $* *$ & $* *$ \\
\hline $\mathbf{C p} \times \mathbf{Y}$ & 1 & NS & NS & $* *$ & 1 & NS & NS \\
\hline $\mathbf{N} \times \mathbf{Y}$ & 3 & $* *$ & $* *$ & $* *$ & 2 & NS & \\
\hline $\mathbf{C p} \times \mathbf{N} \times \mathbf{Y}$ & 3 & NS & NS & NS & 2 & NS & NS \\
\hline $\mathbf{K} \times \mathbf{Y}$ & 3 & $* *$ & $* *$ & NS & 3 & NS & NS \\
\hline $\mathbf{C p} \times \mathbf{K} \times \mathbf{Y}$ & 3 & NS & NS & NS & 3 & NS & NS \\
\hline $\mathbf{K} \times \mathbf{N} \times \mathbf{Y}$ & 9 & $*$ & NS & NS & 6 & NS & NS \\
\hline $\mathbf{C p} \times \mathbf{K} \times \mathbf{N} \times \mathbf{Y}$ & 9 & $*$ & NS & NS & 6 & NS & NS \\
\hline
\end{tabular}

* Indicates significance at $\boldsymbol{P} \leq \mathbf{0 . 0 5}$.

** Indicates significance at $\boldsymbol{P} \leq \mathbf{0 . 0 1}$.

NS Indicates not significant.

(Table 3; Fig. 3). Depending upon the sampling period, tissue $\mathrm{K}$ concentrations peaked between the 81 and 162 $\mathrm{kg} \mathrm{K} \mathrm{ha}{ }^{-1}$ rates, and then decreased thereafter. Concentrations of tissue $\mathrm{K}$ tended to peak higher in 2000 (32-38 $\left.\mathrm{mg} \mathrm{kg}^{-1}\right)$ than in $2001\left(23-26 \mathrm{mg} \mathrm{kg}^{-1}\right)$. Weather conditions in 2001 were much drier than in 2000, and this may have resulted in lower $\mathrm{K}$ uptake under these conditions.

There was no significant correlation between tissue $\mathrm{K}$ concentrations and clipping dry matter yield or quality across the 2 yr of the study (Fig. 4). All but one of the samples had tissue $\mathrm{K}$ concentrations $>10 \mathrm{mg} \mathrm{kg}^{-1}$, and this seems to have been adequate for Kentucky bluegrass needs, regardless of treatment, at this site.

\section{Apparent Nitrogen Recovery and Nitrogen Use Efficiency}

Significant $\mathrm{N}$ rate $\times$ K rate interaction effects were found for apparent $\mathrm{N}$ recovery and use efficiency (Table 1). Apparent $\mathrm{N}$ recovery and use efficiency increased with increasing $\mathrm{K}$ rates for all but the highest level of $\mathrm{N}$ tested, with the response more pronounced as $\mathrm{N}$ rates decreased (Fig. 5A,B).

\section{DISCUSSION}

The positive response of Kentucky bluegrass clipping yields and turf quality to $\mathrm{N}$ in this study adds to the already well-documented effects of $\mathrm{N}$ on turf that are reported in the reviews of Beard (1973) and Turner and 

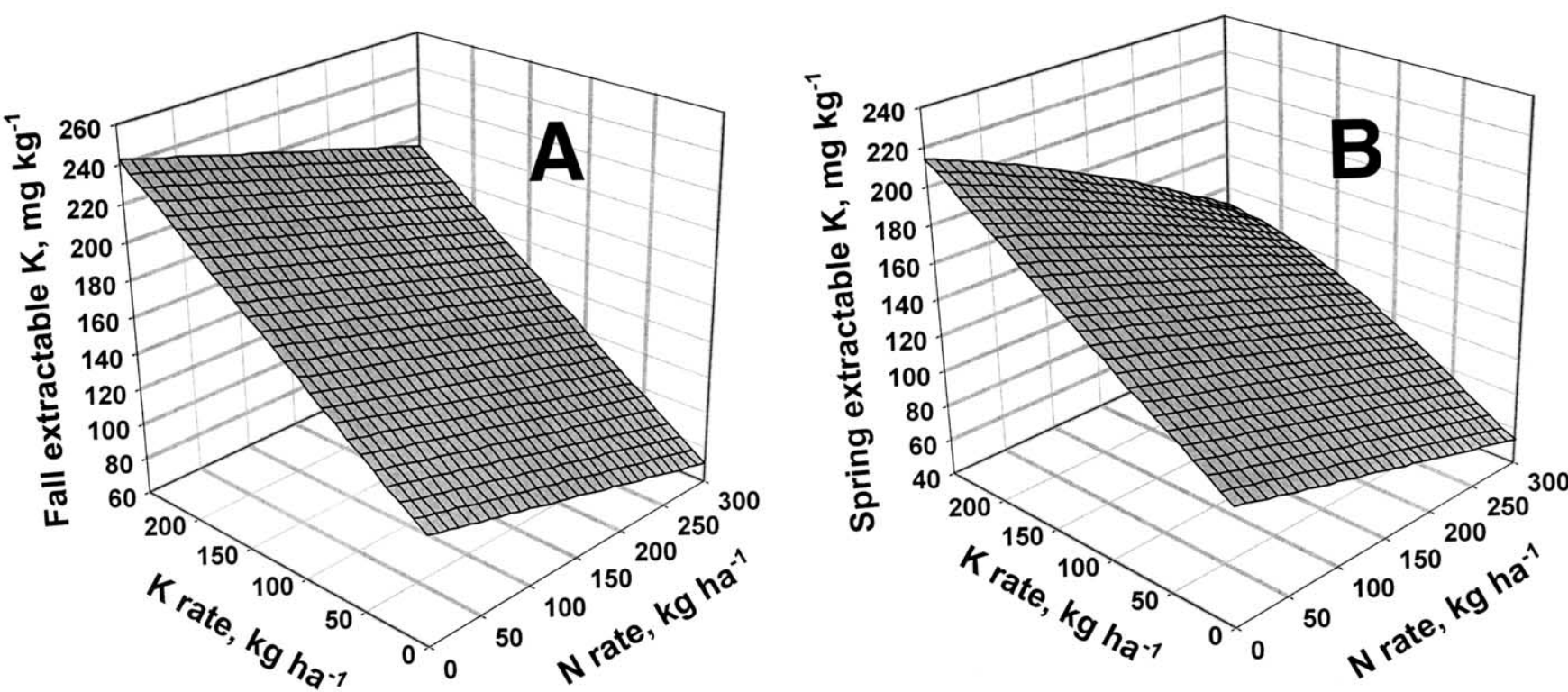

Fig. 1. (A) Predicted fall extractable soil $K$ response surface of Kentucky bluegrass turf fertilized with varying rates of $N$ and $K$. $\hat{y}=118.73-$ $0.158 \mathrm{~N}+0.495 \mathrm{~K} . R^{2}=0.978$. (B) Predicted spring extractable soil $\mathrm{K}$ response surface of Kentucky bluegrass turf fertilized with varying rates of $N$ and $K . \hat{y}=104.10-0.167 \mathrm{~N}+0.442 \mathrm{~K}-4.654 \times 10^{-5} \mathrm{NK}-2.105 \times 10^{-9} \mathrm{NK}^{3}-1.491 \times 10^{-11} \mathrm{~N}^{2} \mathrm{~K}^{3} . R^{2}=0.984$

Hummel (1992). Our observation of an increase in yields and improvements in quality when clippings were returned to the turf was probably attributable to an increase in available $\mathrm{N}$ from the decomposing leaf blades (Starr and DeRoo, 1981; Haley et al., 1985). Returning the clippings may have also reduced water and temperature stresses (Murray and Juska, 1977) and increased Kentucky bluegrass $\mathrm{N}$ recovery and use efficiency

Table 2. Analyses of variance summary indicating significant source effects on Kentucky bluegrass quality and tissue $K$ concentrations.

\begin{tabular}{|c|c|c|c|}
\hline Source & df & Quality & Tissue K \\
\hline Clipping (Cp) & 1 & ** & NS \\
\hline $\mathbf{N}$ rate $(\mathrm{N})$ & 3 & & \\
\hline Linear (L) & 1 & $* *$ & $*$ \\
\hline Quad. (Q) & 1 & $* *$ & NS \\
\hline Cubic (C) & 1 & ** & NS \\
\hline $\mathbf{K}$ rate (K) & 3 & & \\
\hline L & 1 & NS & $*$ \\
\hline $\mathbf{Q}$ & 1 & NS & $* *$ \\
\hline $\mathrm{C}$ & 1 & NS & NS \\
\hline $\mathbf{K} \times \mathbf{N}$ & 9 & & \\
\hline $\mathbf{K} \mathbf{L} \times \mathbf{N L}$ & 1 & NS & NS \\
\hline $\mathbf{K L} \times \mathbf{N Q}$ & 1 & $* *$ & NS \\
\hline $\mathbf{K L} \times \mathbf{N C}$ & 1 & NS & NS \\
\hline $\mathbf{K Q} \times \mathbf{N L}$ & 1 & NS & NS \\
\hline $\mathbf{K Q} \times \mathbf{N Q}$ & 1 & NS & NS \\
\hline $\mathbf{K Q} \times \mathbf{N C}$ & 1 & NS & NS \\
\hline $\mathbf{K C} \times \mathbf{N L}$ & 1 & NS & NS \\
\hline $\mathrm{KC} \times \mathrm{NQ}$ & 1 & NS & NS \\
\hline $\mathrm{KC} \times \mathrm{NC}$ & 1 & NS & NS \\
\hline $\mathbf{C p} \times \mathbf{N}$ & 3 & $* *$ & NS \\
\hline $\mathbf{C p} \times \mathbf{K}$ & 3 & NS & NS \\
\hline $\mathbf{C p} \times \mathbf{K} \times \mathbf{N}$ & 9 & NS & NS \\
\hline Sample period (SP) & 9 & $* *$ & $* *$ \\
\hline $\mathbf{C p} \times \mathbf{S P}$ & 9 & $* *$ & NS \\
\hline $\mathbf{N} \times \mathbf{S P}$ & 3 & $* *$ & $* *$ \\
\hline $\mathbf{C p} \times \mathbf{N} \times \mathbf{S P}$ & 3 & $*$ & NS \\
\hline $\mathbf{K} \times \mathbf{S P}$ & 3 & NS & $* *$ \\
\hline $\mathbf{C p} \times \mathbf{K} \times \mathbf{S P}$ & 3 & NS & NS \\
\hline $\mathbf{K} \times \mathbf{N} \times \mathbf{S P}$ & 9 & NS & NS \\
\hline $\mathbf{C p} \times \mathbf{K} \times \mathbf{N} \times \mathbf{S P}$ & 9 & NS & NS \\
\hline
\end{tabular}

* Indicates significance at $\boldsymbol{P} \leq \mathbf{0 . 0 5}$.

** Indicates significance at $\boldsymbol{P} \leq \mathbf{0 . 0 1}$

NS Indicates not significant.
(Kopp and Guillard, 2002), processes that would contribute to more shoot growth and higher quality turf.

A response to $\mathrm{K}$ was anticipated in this study, considering that the initial extractable soil $\mathrm{K}$ concentration $\left(75 \mathrm{mg} \mathrm{kg}^{-1}\right.$ ) of the experimental area was considered low by our current soil test rating scale. The lack of a positive clipping yield response to $\mathrm{K}$ applications on turfgrass under low soil $\mathrm{K}$ tests, however, has been reported previously. Monroe et al. (1969) found that the highest rate of $\mathrm{K}$ in their study depressed the growth of Kentucky bluegrass, regardless of $\mathrm{N}$ level. With an initial soil $\mathrm{K}$ concentration of $55 \mathrm{mg} \mathrm{kg}^{-1}$ extracted with neutral ammonium acetate, Watschke et al. (1977) observed no significant differences in Kentucky bluegrass

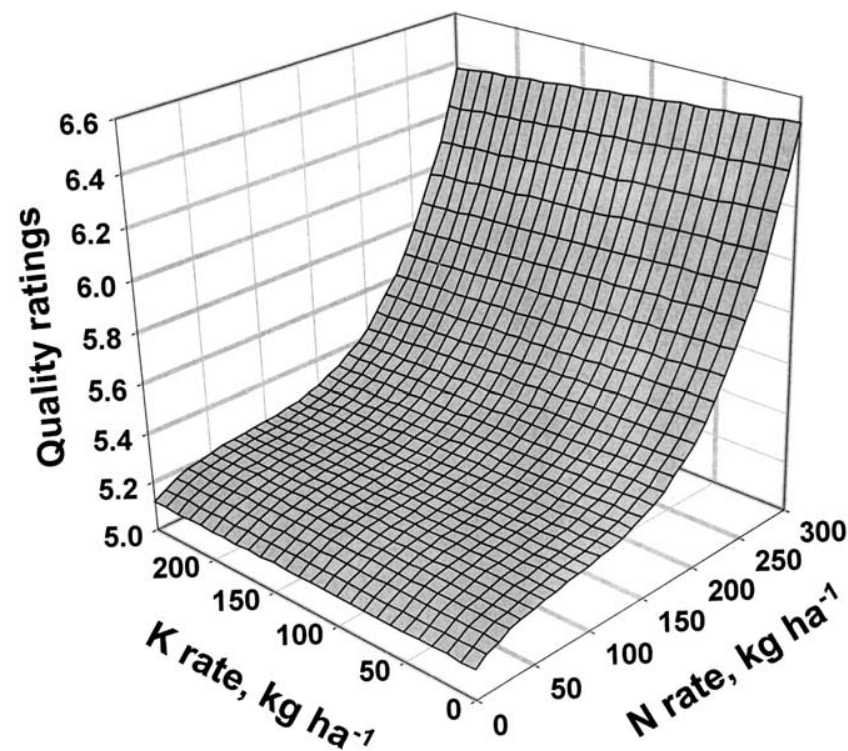

Fig. 2. Predicted quality response surface of Kentucky bluegrass turf fertilized with varying rates of $\mathrm{N}$ and $\mathrm{K} . \hat{\mathrm{y}}=5.12+0.003 \mathrm{~N}-$ $2.805 \times 10^{-5} \mathbf{N}^{2}+1.107 \times 10^{-7} \mathbf{N}^{3}-5.837 \times 10^{-9} N^{2} K . R^{2}=0.239$. 
Table 3. Significance of orthogonal polynomial contrasts for the Sampling Period $\times \mathbf{K}$ rate interaction for Kentucky bluegrass tissue $K$ concentrations.

\begin{tabular}{|c|c|c|c|c|c|}
\hline \multirow[b]{2}{*}{ Contrast } & \multicolumn{5}{|c|}{ Sampling period } \\
\hline & May-June & June-July & July-August & August-September & September-October \\
\hline \multicolumn{6}{|c|}{2000} \\
\hline$K$ rate $L$ & $* *$ & $* *$ & $* *$ & $* *$ & NS \\
\hline $\mathrm{K}$ rate Q & $* *$ & $* *$ & $* *$ & $* *$ & $* *$ \\
\hline $\mathrm{K}$ rate $\mathrm{C}$ & $* *$ & $*$ & $* *$ & $* *$ & $* *$ \\
\hline \multicolumn{6}{|c|}{$\underline{2001}$} \\
\hline$K$ rate $L$ & $* *$ & NS & $* *$ & $*$ & NS \\
\hline $\mathrm{K}$ rate $\bar{Q}$ & $* *$ & ** & NS & $* *$ & NS \\
\hline$K$ rate $\mathrm{C}$ & $* *$ & $* *$ & $*$ & NS & NS \\
\hline
\end{tabular}

* Indicates significance at $\boldsymbol{P} \leq \mathbf{0 . 0 5}$.

** Indicates significance at $\boldsymbol{P} \leq \mathbf{0 . 0 1}$.

NS Indicates not significant.

growth from $\mathrm{K}$ treatments on soil that was considered below optimum in exchangeable K. Others observed no effect of $\mathrm{K}$ alone on the shoot growth of Kentucky bluegrass, grown on a fine sandy loam with an initial soil $\mathrm{K}$ concentration of $9 \mathrm{mg} \mathrm{kg}^{-1}$ (sodium acetate extractant), which was considered low (Ebdon et al., 1999).

Kentucky bluegrass response to $\mathrm{K}$, however, is often dependent upon the availability of other nutrients. Shoot yield of Kentucky bluegrass increased in response to $\mathrm{K}$ at low levels of $\mathrm{N}$, but decreased with $\mathrm{K}$ at high levels of $\mathrm{N}$ (Christians et al., 1981). At P rates below $140 \mathrm{~kg} \mathrm{ha}^{-1}$, turf quality increased in response to $\mathrm{K}$, but decreased with $\mathrm{K}$ at higher rates of $\mathrm{P}$. With $\mathrm{P}$ rates of 64 and $86 \mathrm{~kg} \mathrm{ha}^{-1} \mathrm{yr}^{-1}$, Kentucky bluegrass shoot yields increased in response to $\mathrm{K}$ at low levels of $\mathrm{N}$, but decreased with $\mathrm{K}$ at high levels of $\mathrm{N}$ (Ebdon et al., 1999). In our study, we did not observe a $\mathrm{K}$ and $\mathrm{N}$ interaction yield response with $\mathrm{P}$ applied at $49 \mathrm{~kg} \mathrm{ha}^{-1}$ to plots that initially had Medium availability of P. However, we did observe a slight, but significant, decrease in quality as $\mathrm{K}$ rate increased at the highest $\mathrm{N}$ rate.
The lack of a positive yield or quality response of Kentucky bluegrass to $\mathrm{K}$ fertilization on our sandy loam soil with initial low extractable K levels suggests (i) that our current soil test ratings (Low, Medium, High, etc.) relative to actual concentrations, may underestimate the relationship between extractable $\mathrm{K}$ and expected turf response, and/or (ii) $\mathrm{K}$ from sources other than extractable forms was being supplied to the soil. The supply of extra $\mathrm{K}$ can be suggested by two plausible sources. It is possible that $\mathrm{K}$ was inadvertently added to the plots as a trace constituent of the liming material (Chichilo and Whittaker, 1961). Unfortunately, we do not have a sample of the original liming material to test this hypothesis.

A second more probable explanation, however, is that a substantial amount of $\mathrm{K}$ was being supplied from nonexchangeable forms in the soil. Samples from the plot area produced a mean nonexchangeable soil K concentration of $548 \mathrm{mg} \mathrm{kg}^{-1}$. This suggests that large amounts of $\mathrm{K}$ could become plant available in this soil even if a small percentage of the nonexchangeable $\mathrm{K}$

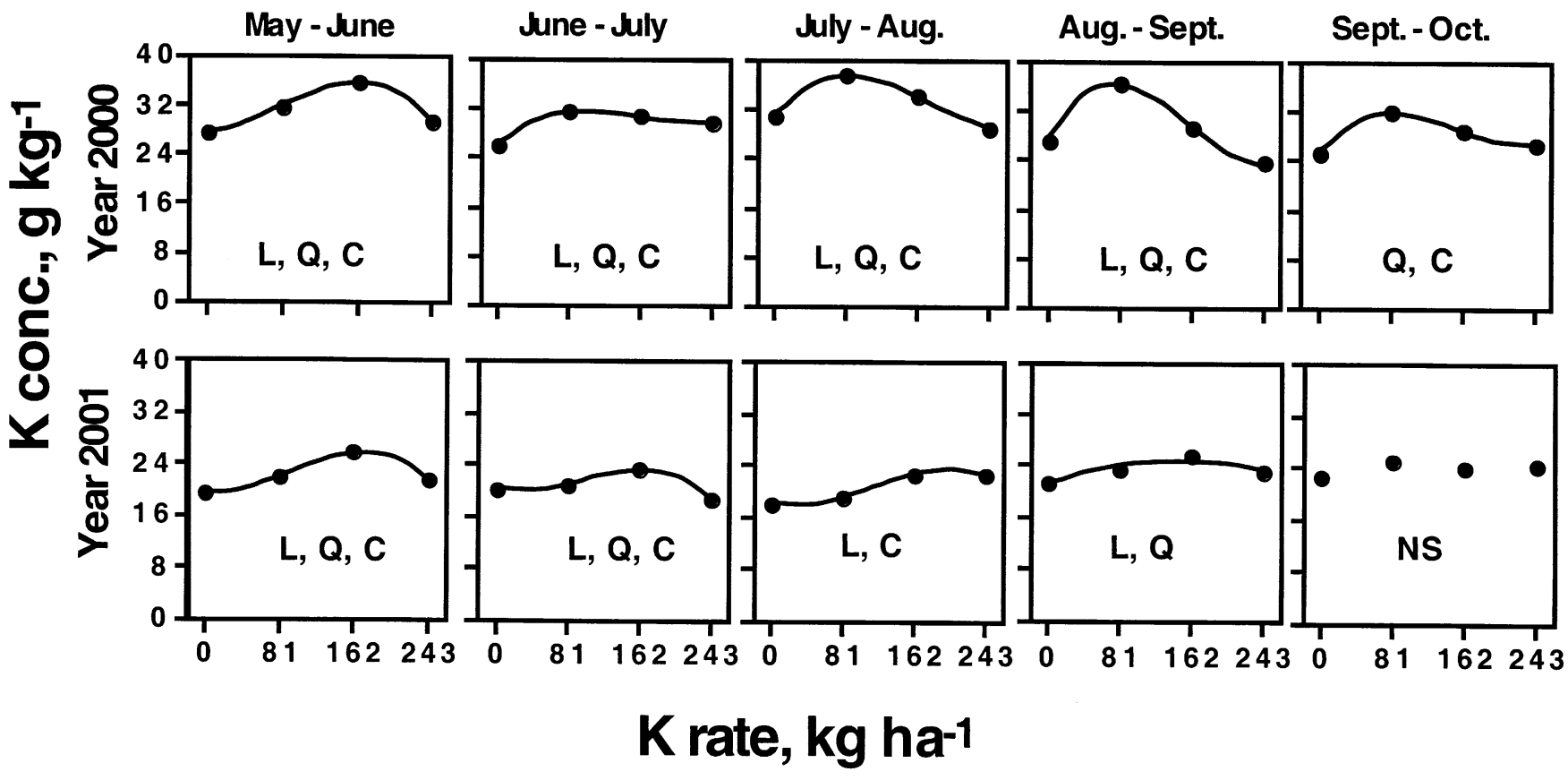

Fig. 3. Potassium fertilization effects on tissue $K$ concentrations of Kentucky bluegrass at five different sampling periods in 2000 and 2001. $\mathbf{L}=$ linear response, $\mathbf{Q}=$ quadratic response, $\mathbf{C}=$ cubic response, $\mathbf{N S}=$ not significant. 

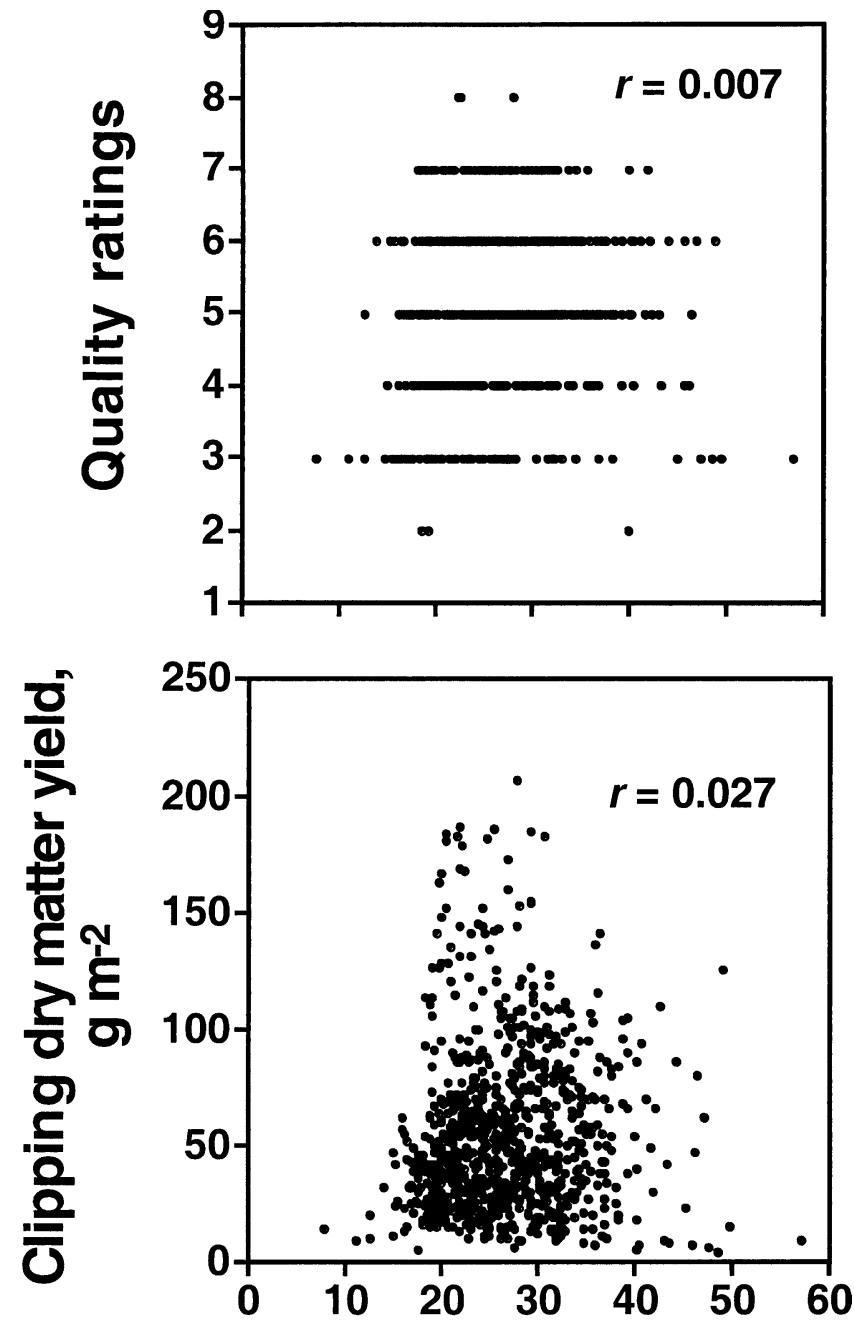

Tissue K conc., $\mathbf{g ~ k g}^{-1}$

Fig. 4. Relationship between tissue $K$ concentration with Kentucky bluegrass quality ratings and clipping dry matter yields. Pearson correlation coefficients $(r)$ are not significant $(p>0.05)$.

was released throughout the growing season. Additionally, X-ray diffraction analysis indicated that the soil at rooting depth was dominated by K-bearing feldspars (data not shown). The mineralogy analysis of sand fractions taken previously at the same site indicated that the mineral composition was approximately $50 \%$ feldspars and $2 \%$ muscovites by volume (Pelletier, 1982), which are both K-bearing minerals. Additionally, the clay types in this soil are predominately illites and vermiculites, which also have the potential to slowly release $\mathrm{K}$ as the levels of exchangeable and soil solution $\mathrm{K}$ decrease.

Our conclusions about $\mathrm{K}$ release from nonexchangable forms are similar to those reported by Dest and Guillard (2001) with creeping bentgrass. Their study suggested that release of $\mathrm{K}$ from primary minerals of certain pure sand rootzone mixes was supplying $\mathrm{K}$ at rates sufficient to meet bentgrass requirements. The lack of crop response to applied $\mathrm{K}$ on some soils has been shown to be due to the large amounts of $\mathrm{K}$ being released from the weathering of the feldspars (Sadusky et al., 1987). Sparks (1980) found that the majority of nonexchangeable $\mathrm{K}$ in Atlantic Coastal Plain soils was contained in feldspars, and suggested that this was responsible for the lack of corn response to applied K.

Across Sampling Periods, mean tissue K concentrations ranged from 18 to $38 \mathrm{~g} \mathrm{~kg}^{-1}$. This range is consistent with the mean tissue $\mathrm{K}$ concentration of $37 \mathrm{~g} \mathrm{~kg}^{-1}$ for Kentucky bluegrass measured by Waddington and Zimmerman (1972) and is within and above the tissue $\mathrm{K}$ concentration sufficiency range for Kentucky bluegrass of 10 to $25 \mathrm{~g} \mathrm{~kg}^{-1}$ suggested by Jones (1980). Control plots receiving no $\mathrm{K}$ yielded relatively high mean tissue $\mathrm{K}$ concentrations, ranging from 23 to $25 \mathrm{~g} \mathrm{~kg}^{-1}$. Of all the tissue samples tested $(>900)$, there was only one sample with $\mathrm{K}$ concentrations $<10 \mathrm{~g} \mathrm{~kg}^{-1}$. These relatively high $\mathrm{K}$ concentrations may indicate that the combination of extractable $\mathrm{K}$ with a portion of the nonexchangeable $\mathrm{K}$ that was released during the growing season were adequate to meet Kentucky bluegrass needs in this sandy loam soil.

The tissue $\mathrm{K}$ concentration response to $\mathrm{K}$ rates suggest that if luxury consumption of $\mathrm{K}$ did occur in this study, it was limited to the first or second increment of $\mathrm{K}$ fertilization, and not concomitant with increasing concentrations of extractable soil K (Fig. 1). Luxury consumption of K was not observed by Miller (1999), Snyder and Cisar (2000), and Sartain (2002) with bermudagrass, nor with Kentucky bluegrass by Monroe et al. (1969) and Schmidt and Breuninger (1981).

Although there was no yield or quality response to $\mathrm{K}$ fertilization, we did observe responses to $\mathrm{K}$ for the $\mathrm{N}$ utilization indices of apparent recovery and use efficiency for all but the highest $\mathrm{N}$ rate. Response surfaces indicated that the greatest recovery and use efficiency occurred at the lowest rates of $\mathrm{N}$ with the highest rates of $\mathrm{K}$. We could find no other reports in the literature that discussed apparent $\mathrm{N}$ recovery or use efficiency with respect to $\mathrm{K}$ fertilization rates or $\mathrm{K}$ availability. Previous studies have indicated positive turfgrass yield and quality responses to $\mathrm{K}$ at low $\mathrm{N}$ rates (Christians et al., 1979; Christians et al., 1981; Ebdon et al., 1999), but have not put forth an explanation for these results. It may be possible that these results of previous studies may be attributed to increased $\mathrm{N}$ recovery and use efficiency at the low $\mathrm{N}$ rates with high $\mathrm{K}$.

The positive effect of increasing $\mathrm{K}$ on both $\mathrm{N}$ recovery or use efficiency at the lower $\mathrm{N}$ rates may have been influenced by the effects of $\mathrm{K}$ fertilization on root development. Although we did not measure root growth in response to $\mathrm{K}$, this hypothesis is supported by studies made by Monroe et al. (1969) and Bowman et al. (1998). Kentucky bluegrass rhizome lengths increased with added $\mathrm{K}$ at the low rate of $\mathrm{N}$, but not at the high rate of $\mathrm{N}$ in the Monroe et al. (1969) study. Bowman et al. (1998) reported that deep-rooted bentgrass genotypes absorbed $\mathrm{N}$ more efficiently than shallow-rooted genotypes. Similarly, studies of the belowground morphological traits of Kentucky bluegrass indicated that the fibrous root length was positively correlated with the nitrate uptake rate (Sullivan et al., 2000). Our results suggest that further studies should be conducted to ex- 

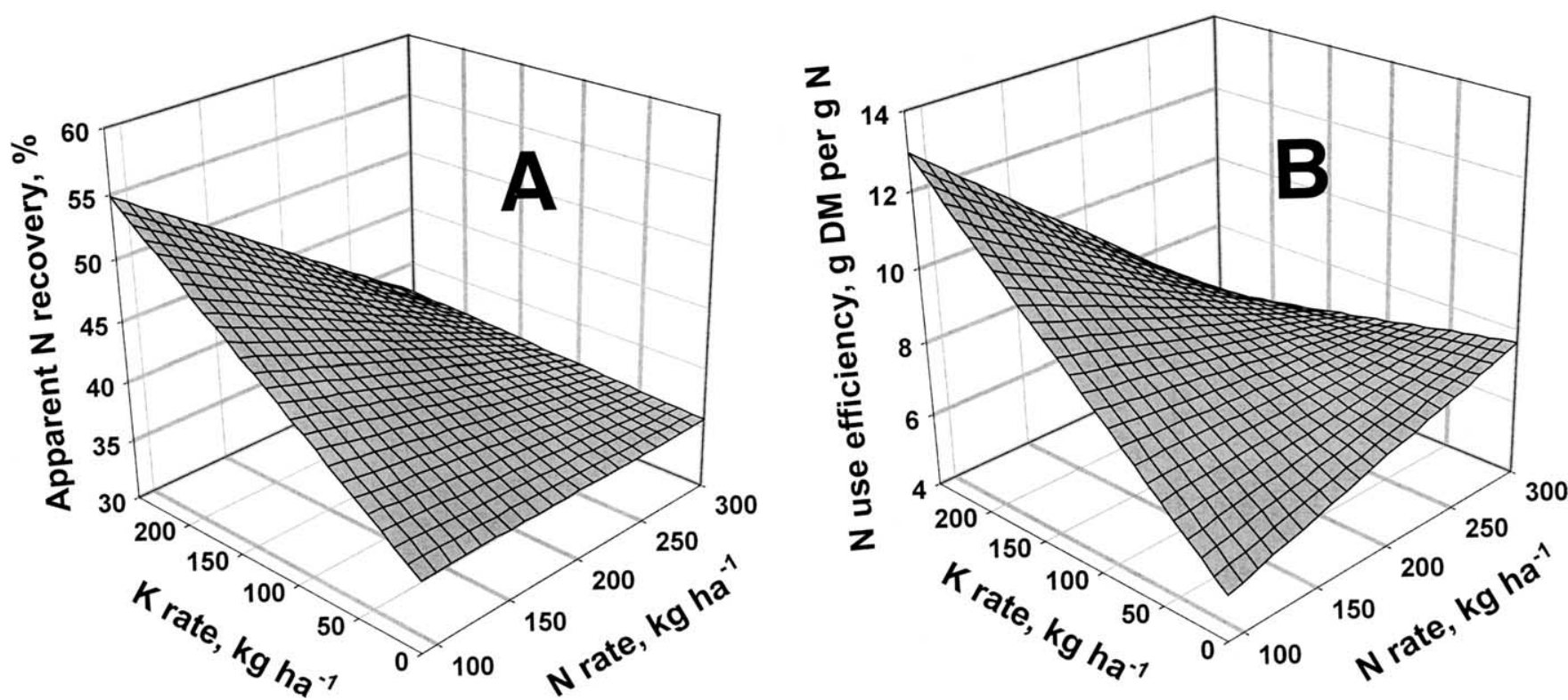

Fig. 5. (A) Predicted apparent $N$ recovery response surface of Kentucky bluegrass turf fertilized with varying rates of $N$ and K. $\hat{y}=35.771+$ $0.106 \mathrm{~K}-3.332 \times 10^{-4} \mathrm{NK} . R^{2}=0.750$. (B) Predicted $\mathrm{N}$ use efficiency response surface of Kentucky bluegrass turf fertilized with varying rates of $\mathrm{N}$ and $\mathrm{K} . \hat{y}=4.126+0.012 \mathrm{~N}+0.047 \mathrm{~K}-1.816 \times 10^{-4} \mathrm{NK} . R^{2}=0.860$.

plore the $\mathrm{K}$ fertilization effects under varying $\mathrm{N}$ rates on both root growth and enhanced $\mathrm{N}$ recovery or use efficiency.

This finding of increased $\mathrm{N}$ recovery and use efficiency with increasing $\mathrm{K}$ may have applicability in situations were $\mathrm{N}$ applications to turf are restricted or of concern, such as in environmentally sensitive areas. By applying lower $\mathrm{N}$ rates in combination with higher $\mathrm{K}$ rates, the threat of $\mathrm{N}$ pollution to receiving waters may be lessened and turf quality maintained at acceptable levels through an increase in $\mathrm{N}$ recovery and/or use efficiency. It has been reported that less $\mathrm{N}$ and more $\mathrm{K}$ were required to maximize Kentucky bluegrass quality than to maximize shoot production (Christians et al., 1979).

Under conditions where soil extractable concentrations of $\mathrm{Ca}$ and $\mathrm{Mg}$ are low such as in sand-based rootzone mixes or sandy native soils, high $\mathrm{K}$ rates may induce $\mathrm{Ca}$ and $\mathrm{Mg}$ deficiencies of turf (Miller, 1999). This may negate the enhancement of $\mathrm{N}$ recovery and use efficiency by increased $\mathrm{K}$ rates in these situations. In our study, fall extractable soil $\mathrm{Ca}$ and $\mathrm{Mg}$ concentrations declined slightly in response to increasing $\mathrm{K}$ rates, but there was no $\mathrm{K}$ effect found for spring samples (data not shown). The $\mathrm{Ca}$ and $\mathrm{Mg}$ availability for fall samples, however, remained in the Medium and Medium High categories, respectively; we did not observe $\mathrm{Ca}$ or $\mathrm{Mg}$ deficiencies.

\section{CONCLUSIONS}

There were no positive Kentucky bluegrass yield or quality responses to $\mathrm{K}$ fertilization, even though initial soil extractable $\mathrm{K}$ concentrations were considered low. Relatively high tissue K concentrations suggest that sufficient soil $\mathrm{K}$ was available to meet the requirements for Kentucky bluegrass growth and quality at this site without $\mathrm{K}$ fertilization. The results further suggest that our current $\mathrm{K}$ recommendations based on extractable soil $\mathrm{K}$ levels need to be revised and/or that extractable $\mathrm{K}$ levels alone do not adequately predict the amount of $\mathrm{K}$ available to Kentucky bluegrass on this soil. The inclusion of a portion of the nonexchangeable $\mathrm{K}$ amount with the extractable $\mathrm{K}$ levels to estimate $\mathrm{K}$ availability to Kentucky bluegrass may be warranted for our sandy loam soil. Increasing the $\mathrm{K}$ rate relative to the $\mathrm{N}$ rate may help to reduce the threat of $\mathrm{N}$ pollution by increasing $\mathrm{N}$ recovery and use efficiency.

\section{ACKNOWLEDGMENTS}

Partial funding for this study was provided by the Potash \& Phosphate Institute. The authors are appreciative of this funding and thank the Institute for their support.

\section{REFERENCES}

Baker, J.H., and T. Greweling. 1967. Extraction procedure for quantitative determination of six elements in plant tissue. J. Agric. Food Chem. 15:340-344.

Beard, J.B. 1973. Turfgrass: Science and culture. Prentice Hall, Inc., Englewood Cliffs, N.J.

Bowman, D.C., D.A. Devitt, M.C. Engelke, and T.W. Rufty, Jr. 1998. Root architecture affects nitrate leaching from bentgrass turf. Crop Sci. 38:1633-1639.

Carroll, M.J., and A.M. Petrovic. 1991. Nitrogen, potassium, and irrigation effects on water relations of Kentucky bluegrass leaves. Crop Sci. 31:449-453.

Chapman, H.D., and P.F. Pratt. 1978. Methods of analysis for soils, plants and waters. Pub. 4034. Univ. of California, Riverside, CA.

Chichilo, P., and C.W. Whittaker. 1961. Trace elements in agricultural limestones of the US. Agron. J. 53:139-144.

Christians, N.E., D.P. Martin, and K.J. Karnok. 1981. The interactions among nitrogen, phosphorus and potassium on the establishment, quality, and growth of Kentucky bluegrass (Poa pratensis L. 'Merion'). p. 341-348. In R.W. Sheard (ed.) Proc. 4th Intl. Turfgrass Res. Conf., Guelph, Canada. 19-23 July 1981. Int. Turfgrass Soc., Ontario Agric. Coll., Univ. of Guelph, Guelph, ON.

Christians, N.E., D.P. Martin, and J.F. Wilkinson. 1979. Nitrogen, 
phosphorus, and potassium effects on quality and growth of Kentucky bluegrass and creeping bentgrass. Agron. J. 71:564-567.

Dest, W.M., and K. Guillard. 2001. Bentgrass response to K fertilization and $\mathrm{K}$ release rates from eight sand rootzone sources used in putting green construction. Int. Turfgrass Soc. Res. J. 9:375-381.

Ebdon, J.S., A.M. Petrovic, and R.A. White. 1999. Interaction of nitrogen, phosphorus, and potassium on evapotranspiration rate and growth of Kentucky bluegrass. Crop Sci. 39:209-218.

Gomez, K.A., and A.A. Gomez. 1984. Statistical procedures for agricultural research. 2nd ed. John Wiley \& Sons, New York.

Güzel, N., G. Büyük, and H. Ibrikei. 2001. Non-exchangeable and exchangeable potassium status of soils in relation to clay mineralogy and other soil properties in Hilvan area of Upper Mesopotamia in southeastern Anatolia. Commun. Soil Sci. Plant Anal. 32:28772892

Haley, J.E., D.J. Wehner, T.W. Fermanian, and A.J. Turgeon. 1985. Comparison of conventional and mulching mowers for Kentucky bluegrass maintenance. HortScience 20:105-107.

Helmke, P.A., and D.L. Sparks. 1996. Boiling nitric acid extraction method. p. 561-562. In J.M. Bigham (ed.) Methods of soil analysis. Chemical methods. Part 3. Agron. Monogr. 9. SSSA and ASA, Madison, WI.

Hunt, J. 1982. Dilute hydrochloric acid extraction of plant material for routine cation analysis. Commun. Soil Sci. Plant Anal. 13:49-55.

Jones, J.R., Jr. 1980. Turf analysis. Golf Course Manage. 48(1):29-32.

Kopp, K.L., and K. Guillard. 2002. Clipping management and nitrogen fertilization of Turfgrass: Growth, nitrogen utilization, and quality. Crop Sci. 42:1225-1231.

López-Piñeiro, A., and A. García Navarro. 1997. Potassium release kinetics and availability in unfertilized vertisols of southwestern Spain. Soil Sci. 162:912-918.

McIntosh, J.L. 1969. Bray and Morgan soil extractants modified for testing acid soils from different parent materials. Agron. J. 61:259265.

Miller, G.L. 1999. Potassium application reduces calcium and magnesium levels in bermudagrass leaf tissue and soil. HortScience 34:265268.

Mitchell, J.K. 1993. Fundamentals of soil behavior. John Wiley \& Sons, New York.

Monroe, C.A., G.D. Coorts, and C.R. Skogley. 1969. Effect of nitrogen-potassium levels on the growth and composition of Kentucky bluegrass. Agron. J. 61:294-296.

Murray, J.J., and F.V. Juska. 1977. Effect of management practices on thatch accumulation, turf quality, and leaf spot damage in common Kentucky bluegrass. Agron. J. 69:365-369.

Nelson, L.R., T.C. Keisling, and F.M. Rouquette, Jr. 1983. Potassium rates and sources for 'Coastal' bermudagrass. Soil Sci. Soc. Am. J. 47:963-966.

Pelletier, M.L. 1982. Characterization of three well-drained upland soils in Eastern Connecticut, and their relationship to the regional till stratigraphy. MS Thesis, University of Connecticut, Storrs, CT.

Pellet, H.M., and E.C. Roberts. 1963. Effects of mineral nutrition on high temperature induced growth retardation of Kentucky bluegrass. Agron. J. 55:473-476.

Percell, W.M., D.D. Howard, and M.E. Essington. 1995. Relationship between total and extractable cotton leaf potassium in studies involving soil and foliar applied treatments. Commun. Soil Sci. Plant Anal. 26:3121-3131.

Sadusky, M.C., D.L. Sparks, M.R. Noll, and G.J. Hendricks. 1987. Kinetics and mechanisms of potassium release from sandy Middle Atlantic Coastal Plain soils. Soil Sci. Soc. Am. J. 51:1460-1465.

Sahrawat, K.L. 1980. A rapid nondigestion method for determination of potassium in plant tissue. Commun. Soil Sci. Plant Anal. 11:753757.

Sartain, J.B. 1993. Interrelationships among turfgrasses, clipping recycling, thatch, and applied calcium, magnesium, and potassium. Agron. J. 85:40-43.

Sartain, J.B. 2002. Tifway bermudagrass response to potassium fertilization. Crop Sci. 42:507-512.

Schabenberger, O., and F.J. Pierce. 2002. Contemporary statistical models for the plant and soil sciences. CRC Press, Boca Raton, FL.

SAS Institute. 1999. SAS onlinedoc, Version 8. Cary, NC.

Schmidt, R.E., and J.M. Breuninger. 1981. The effects of fertilization on recovery of Kentucky bluegrass turf from summer drought. p. 333-339. In R.W. Sheard (ed.) Proc. 4th Int. Turfgrass Res. Conf., Guelph. 19-23 July 1981. Int. Turfgrass Soc., Ontario Agric. Coll., Univ. of Guelph, Guelph, ON.

Skogley, C.R., and C.D. Sawyer. 1992. Field research. p. 589-614. In D.V. Waddington et al (ed.) Turfgrass. Agron. Monogr. 32. ASA, CSSA, and SSSA, Madision, WI.

Snyder, G.H., and J.L. Cisar. 2000. Nitrogen/Potassium fertilization ratios for bermudagrass turf. Crop Sci. 40:1719-1723.

Sparks, D.L. 1980. Chemistry of soil potassium in Atlantic Coastal Plain soils: A review. Commun. Soil Sci. Plant Anal. 11:435-449.

Starr, J.L., and H.C. DeRoo. 1981. The fate on nitrogen fertilizer applied to Turfgrass. Crop Sci. 21:531-536.

Sullivan, W.M., Z. Jiang, and R.J. Hull. 2000. Root morphology and its relationship with nitrate uptake in Kentucky bluegrass. Crop Sci. 40:765-772.

Turner, T.R., and N.W. Hummel, Jr. 1992. Nutritional requirements and fertilization. p. 385-439. In D.V. Waddington et al. (ed.) Turfgrass. Agron. Monogr. 32. ASA, CSSA, and SSSA, Madision, WI.

Waddington, D.V., and T.L. Zimmerman. 1972. Growth and chemical composition of eight grasses grown under high water table conditions. Commun. Soil Sci. Plant Anal. 3(4):329-337.

Watschke, T.L., D.V. Waddington, D.J. Wehner, and C.L. Forth. 1977. Effect of $\mathrm{P}, \mathrm{K}$, and lime on growth, composition, and $\mathrm{P}$ absorption by Merion Kentucky bluegrass. Agron. J. 69:825-828.

Wedin, W.F. 1974. Fertilization of cool-season grasses. p. 95-118. In D.S. Mays (ed.) Forage fertilization. ASA, CSSA, and SSSA, Madison, WI.

Zemenchik, R.A., and K.A. Albrecht. 2002. Nitrogen use efficiency and apparent nitrogen recovery of Kentucky bluegrass, smooth bromegrass, and orchardgrass. Agron. J. 94:421-428. 